\title{
NOWE FORMY ARCHITEKTURY KRAJOBRAZU KSZTAŁTUJĄCE STRUKTURY MIAST PRZYSZŁOŚCI - WYKORZYSTANIE MIKROALG
}

\begin{abstract}
W nowej, "ekologicznej" erze budynki, parki, ciągi komunikacyjne powinny nie tylko kreować przestrzeń, ale promować nowe koncepcje związane ze świadomością odpowiedzialnego użytkowania środowiska naturalnego w miastach. Narzędziem do wdrożenia tego niesłychanie ważnego zdania mogą zostać mikroalgi. Ich zastosowanie w najprostszej postaci polega na użyciu ich jako elementu fasad budynków, zielonych części ciągów komunikacyjnych oraz jako instalacji w parkach miejskich. Mikroalgi oprócz funkcji dekoracyjnych mogą w przyszłości stać się ważnym elementem w produkcji tlenu, redukcji dwutlenku węgla, oczyszczania zanieczyszczeń z wody oraz produkcji biopaliw i żywności - gdzie budynki, parki, pasaże zmienią swój charakter z pasywnego na mający zdolność adoptowania się i dostosowania do aktualnych potrzeb użytkowników, jako żyjący, oddychający obiekt wspomagający zrównoważone funkcjonowanie miast przyszłości.
\end{abstract}

Słowa kluczowe: mikroalgi, fotobioreaktor, zielona ściana, współczesna architektura krajobrazu

\section{Wprowadzenie - znacznie funkcjonalnych kompozycji roślinnych we współczesnych miastach na przykładzie zastosowania fotobioreaktorów $\mathrm{z}$ mikroalgami}

W dzisiejszych czasach powstaje coraz więcej nowych form architektury krajobrazu, które mają za zadanie nie tylko kreować estetyczny wizerunek miasta, ale również korzystnie wpływać na kształtowanie się jego klimatu, redukcję $\mathrm{CO}_{2}$, oczyszczanie i magazynowanie wody, a nawet produkcję żywności. Coraz częściej dla projektantów ważne stają się problemy ochrony środowiska oraz zwiększenia bioróżnorodności w miastach (fauna i flora), a także przeciwdziałanie negatywnym skutkom urbanizacji. Stąd tak wiele nowych form kształtowania zieleni miejskiej odnosi się do skali małej, bezpośrednio związanej ze struk-

\footnotetext{
${ }^{1}$ Agnieszka Dudzińska-Jarmolińska, Uniwersytet Warszawski, Wydział Geografii i Studiów Regionalnych, Instytut Studiów Regionalnych i Globalnych, Zakład Geografii Rozwoju i Planowania Przestrzennego, ul. Krakowskie Przedmieście 32, 00-927 Warszawa; tel. 02255232 44; a.dudzinska-ja@uw.edu.pl
} 
turą budynku lub jego bliską obecnością. W dzisiejszych czasach tradycyjne formy kształtowania architektury krajobrazu stają się zbyt drogie i nieadekwatne do oczekiwań użytkowników i mieszkańców miast. Dlatego też architekci krajobrazu powinni coraz częściej sięgać po struktury, które można nazwać "roślinnymi kompozycjami funkcjonalnymi" spełniającymi konkretne i istotne funkcje w mieście. Takimi kompozycjami mogą stać się obiekty, które w swojej strukturze zawierają mikroalgi.

Mikroalgi to organizmy małe, przeważnie jednokomórkowe, tak jak inne rośliny w procesie fotosyntezy wytwarzają biomasę, wykorzystując energię słoneczną, $\mathrm{CO}_{2}$ oraz substancje organiczne zawarte w wodzie. Przy czym mikroalgi przeprowadzają proces fotosyntezy bardzo wydajnie, przez co produkują dziesięciokrotnie więcej tlenu niż np. drzewa. Można również znaleźć gatunki alg, które wytwarzają biomasę bez udziału światła wykorzystując do tego cukry [6].

\section{Znaczenie mikroalg w kształtowaniu miast zrównoważonych}

Mikroalgi zasiedlają wody słone i słodkie, a także wilgotne powierzchnie gleb. Mogą one podwajać swoją masę w czasie krótszym niż 24 godziny [6]. Posiadają wiele pozytywnych cech fizjologicznych, które nie tylko w przyszłości, ale już dzisiaj mogą wywierać znaczący wpływ na kształtowanie się miast proekologicznych. Glony te potrafią między innymi oczyszczać wodę z metali ciężkich.

Coraz częściej bierze się je pod uwagę przy produkcji biopaliw w biorafineriach (produkcja: biodiesla, bioetanolu, biogazu lub biowodoru). Można je również poddawać procesowi spalania w kogeneratorach, by uzyskać energię elektryczną oraz ciepło [3]. Może to skutecznie zmniejszyć zużycie paliw kopalnych wykorzystywanych do produkcji energii, a co za tym idzie - przyczynić się do zmniejszenia degradacji środowiska naturalnego.

Mikroalgi mogą również stać się elementem miejskiego rolnictwa. Już dziś uważa się, iż posiadają one wiele składników bioaktywnych (nienasycone kwasy tłuszczowe, barwniki i antyoksydanty). Mogą być źródłem witamin niezbędnych dla prawidłowego funkcjonowania ludzkiego organizmu, a także wielu bardzo cennych minerałów [4].

Mikroalgi hodowane są w otwartych basenach (niemniej jednak ta forma hodowli zajmuje zbyt dużą powierzchnię) lub też w specjalnych pojemnikach zwanych fotobioreaktorami, które mają różne kształty: między innymi płaskie prostopadłościany ustawione $\mathrm{w}$ poziomie lub pod kątem, albo cylindryczne przypominające formą długą rurę [4].

Obecnie w przestrzeni miast mikroalgi możemy spotykać na elewacjach budynków oraz jako samodzielne instalacje zlokalizowane na terenach parków i placów miejskich. W przyszłości mogą one stać się elementem umożliwiającym człowiekowi eksplorację kosmosu [5]. 


\section{Metodyka i wyniki badań}

Przeprowadzone badania miały charakter dwuetapowy. W pierwszej kolejności zapoznano się z dostępnymi źródłami pisanymi takimi jak: literatura naukowa, materiały konferencyjne, opracowania akademickie oraz dostępne w sieci internetowej koncepcje architektoniczne i urbanistyczne. Następnie powyższe badania zostały skonfrontowane $\mathrm{z}$ istniejącymi projektami zastosowania mikroalg, które powstały na świecie w przeciągu ostatnich dwóch lat w podobnej do polskiej strefie klimatycznej. Dzięki tak podjętej analizie rozwiązań projektowych można przypuszczać, iż tego typu nowe formy architektury krajobrazu będzie można w przyszłości zastosować również w Polsce.

W wyniku podjętych badań i analiz tego typu "kompozycje funkcjonalne" podzielono na trzy grupy: wykorzystanie mikroalg jako elementu elewacji na ścianie budynku, kreowania przestrzeni parkowych oraz placów miejskich.

\subsection{Fotobioreaktory $\mathrm{z}$ mikroalg jako zielone ściany}

Budynki zlokalizowane w miastach są odpowiedzialne za wytwarzanie ok. $40 \%$ światowego $\mathrm{CO}_{2}$, co jak wiadomo prowadzi do niekorzystnych zmian klimatycznych. Alternatywą dla tradycyjnych elewacji budynków mogą być szklane fasady wypełnione roztworem zasiedlonym przez mikroalgi [7].

Pierwsze fotobioreaktory, gdzie hodowane są mikroalgi na ścianach budynków, powstały w przeciągu kilku ostatnich lat. Pierwszym budynkiem gdzie zastosowano tego typu elementy jest obiekt zwany BIQ [1].

Instalację założono na dwóch ścianach po stronie południowo-wschodniej oraz zachodniej [2], przez co budynek zyskał możliwość produkcji ciepła i energii[1]. Mikroalgi zastosowane w tym projekcie odżywiają się $\mathrm{CO}_{2}$, azotem, fosforem i mikroelementami zawartymi w wodzie pitnej. Hodowla przeprowadzana jest w obiegu zamkniętym, tak by mieć jak najmniejsze starty wody i składników odżywczych [2]. Gdy panel dojrzeje, algi są okresowo gromadzone, przetwarzane, a następnie spalane w miejscowej elektrowni w celu wytworzenia energii elektrycznej. W tym celu oddziela się masę mikroalg od wody, którą następnie zużywa się do prowadzenia nowej hodowli [10]. Ściana z alg działa jak termostat $[1,2]$ i nie pozwala budynkowi zarówno nadmiernie się nagrzewać latem, jak i zbytnio wychładzać zimą [1]. Elewacja składa się z 129 modułów reaktorów, o szerokości $70 \mathrm{~cm}$, wysokości $270 \mathrm{~cm}$ i $8 \mathrm{~cm}$ grubości. Panele osadzone są w metalowych ramach, gdzie znajdują się instalacje, którymi dostarczana jest pożywka oraz $\mathrm{CO}_{2}$ wraz zanieczyszczonym przez rożnego rodzaje spaliny powietrzem. Dzięki temu hodowla jest w ciągłym ruchu, glony nie opadają na dno i są równomiernie naświetlone. W czasie dnia słońce nagrzewa panele do temperatury $35^{\circ} \mathrm{C}$. Ciepło odprowadzane jest z budynku przez wymiennik ciepła [2]. Technologia została stworzona przez SSC Strategic Science Consult, we współpracy z Arup. 
Elewacje budynków pokrytych fotobioreaktorami mogą przybierać rożne kształty, np. po modernizacji obiektu GSA (General Services Administration) znajdującego się w Los Angeles, elewacja zyska zbiorniki z algami w formie poziomo ułożonych rur. W instalacji tej rury będą ze sobą połączone, a jej zadaniem będzie między innym oczyszczanie ścieków i powietrza z pobliskiej autostrady. Projekt modernizacji został wykonany przez pracownię HOK [16].

W przyszłości tego typu fasady mogą pełnić wiele funkcji:

- ciepło może być wykorzystane do przygotowania ciepłej wody użytkowej lub też magazynowane,

- energia wytworzona bezpośrednio z mikroalg w biogazowniach (zbiór następuje raz w tygodniu) może być wykorzystywana przez miasto na własny użytek [2],

- wykorzystanie naturalnego światła dziennego w budynkach nie tylko pozwala obniżyć koszty związane z nadmiernym wykorzystaniem energii i wytwarzaniem ciepła, ale przyczynia się do zmniejszenia ilości absencji pracowników w ciągu roku. Elewacje z mikroalg wychwytują konkretną barwę światła (zieloną, niebieską lub czerwoną), dzięki czemu do pomieszczenia dostają się barwy korzystne dla funkcjonowania człowieka [7,8],

- w czasie namnażania się mikoralag, przy silnej operacji słonecznej, dochodzi do zmiany koloru i (gęstości ilości) roślin w panelu, co prowadzi do zmniejszenia przepuszczalności światła, a co za tym idzie, zacienienia budynku dzięki czemu obiekt nadmiernie się nie nagrzewa [8],

- tego typu elewacje mogą również pełnić funkcje izolacyjne przed hałasem, który może wywoływać wiele schorzeń u człowieka.

\subsection{Kształtowanie przestrzeni parkowych}

Właściwości kolorystyczne mikroalg (spirulina - Arthrospira platensis) wykorzystano w projekcie znajdującym się w Genewie. W brzozowym lesie zainstalowano fontannę wypełnioną wodą o intensywnie niebiesko - zielonym odcieniu zasiedlaną przez mikroalgii. Fontanna swoją formą nawiązuje do projektu kaskady wodnej w Villa Aldo Brandini zbudowanej w 1550 we Frascati niedaleko Rzymu. Zachowano nie tylko wygląd historyczny, ale również nie zmieniono rozmiarów założenia. Twórcami projektu jest zespół Burea A., który chciał pokazać, w jaki sposób można kształtować nowoczesne rolnictwo miejskie w przestrzeniach codziennych, gdzie poprzez kontekst historyczny nadający im romantyczny charakter - stają się tak bliskie wielu odbiorcom. Jednocześnie cały projekt znakomicie wpisuje się w naturalną przestrzeń parku i stanowi zaskakujący, estetyczny element przestrzeni, w pewnym stopniu wtapiając się w nią [14].

Innym projektem eksponowanym na terenie parku są metalowe konstrukcje wypełnione roztworem z mikroalgami, nawiązujące swą formą do drzew. Instalacja "Alga (e) Zebo" została zlokalizowana w części olimpijskiej wioski (Euston Square Gardens) w Londynie w 2012 roku. Ażurowe rzeźby z metalu (ma- 
teriał z recyklingu) spełniały funkcje altan i stanowiły punkt spotkań dla osób przebywających $\mathrm{w}$ tej części miasta. Ażurowa forma pozwalała na kreowanie różnego rodzaju światłocienia w przestrzeni parku, wtapiając się między rosnące tam drzewa i krzewy, a jednocześnie tego typu konstrukcje mogą stać się podporami dla roślinności pnącej. Wewnątrz konstrukcji umieszczono fotobioreaktory wypełnione mikroalgami różnych gatunków charakteryzujących się odmienną kolorystyką [12].

Przestrzenią gdzie został zaaranżowany "Algea Garden" jest park miejski znajdujący się w Quebecu. Projekt został wykonany przez Synnove Fredericks i Brende Parker. Obiekt powstał w ramach festiwalu Metis International Garden Festival. Wodny ogród składa się z prostych drewnianych ram, na których rozpięto plastikowe rury wypełnione roztworem zasiedlonym przez różne gatunki mikroalg. Instalacja została wykonana w celu nawiązania interakcji z odbiorcą przestrzenni. Każdy może przyczynić się do produkcji miroalg w instalacji poprzez wtłaczanie do wnętrza plastikowych tub dwutlenku węgla. Tuby zasiedlają z kolei mikroalgi różnych gatunków, przez co w przyszłości instalacja będzie mienić się wieloma kolorami oraz świecić w ciemności (bioluminescencja). "Żywa rzeźba" spełnia więc nie tylko funkcje estetyczne, ale również edukacyjne, pokazując bogactwo gatunków i ich różnorodność, uczy również tego, w jaki sposób mikroalgi będzie można wykorzystać w przyszłości $[9,15]$.

\subsection{Kształtowanie placów miejskich}

Mikroalgi mogą być również elementem tworzonych instalacji wzbogacających walory wizualne przestrzeni miejskiej, a jednocześnie pełnić konkretne funkcje względem użytkowników i otaczającego ich środowiska.

W projekcie "Urban Algae Folly" mikroalgi wykorzystano w konstrukcji elewacji bioaltany, która stanęła na Placu Republiki portugalskiego miasta Braga w 2015 roku. Instalacja ta nie tylko pokazuje, iż mikroalgi mogą stać się ważnym składnikiem miejskiego rolnictwa, ale spełnią także wiele innych istotnych funkcji ważnych dla osób korzystających z przestrzeni placu. Pawilon składa się bioreaktorów wypełnionych mikroargami (chlorella) rozpiętych na konstrukcji altany niczym skóra. Biostruktury składają się z trzech warstw materiału ETFE, w których zostały umieszczone mikroalgi. Jest ona w stanie kontrolować przepływ energii, wody i dwutlenku węgla używając do tego zmieniających się danych konkretnego środowiska, pogody i ilości użytkowników danego obszaru. Dzięki temu konstrukcja zyskuje swoistego rodzaju morfologię i może dynamicznie ulegać zmianie poprzez sterowanie zacienieniem czaszy - w zależności od aktualnych potrzeb. Gotowa czasza będzie w stanie wytworzyć tyle tlenu, ile wyprodukowałby czterohektarowy las, tj. $150 \mathrm{~kg}$ biomasy dziennie (z czego $60 \%$ procent stanowią naturalne białka roślinne) [11]. Tworząc swojego rodzaju zadaszenie, w cieniu którego może schronić się użytkownik jednocześnie wydychający $\mathrm{CO}_{2}$, przyczynia się do zwiększenia produkcji $\mathrm{O}_{2}$ przez algi. Pawilon 
został zaprojektowany przez ecoLogicStudio, ma spełniać funkcje drzew oraz instalacji artystycznej. Po raz pierwszy prototyp pawilonu został zaprezentowany w czasie wystawy Expo w Mediolanie w 2015 roku. System został opracowany przez ecoLogicStudio we współpracy z Taiyo Europa.

\section{Podsumowanie}

W dzisiejszych czasach musimy podejmować jak najwięcej działań prowadzących do wykorzystywania nowych form aranżacji zieleni w miastach. Nowymi - do tej pory niewykorzystywanymi formami - są algi. Mogą one nie tylko subtelnie oświetlać najbliższe otoczenie, produkować tlen jednocześnie oczyszczając powietrze z zanieczyszczeń, ale również wytwarzać energię. Będą mogły również regenerować środowisko naturalne oczyszczając i magazynując wodę deszczową. Mogą stać się elementem elewacji budynków, dzięki czemu zmniejszone zostaną straty ciepła lub - w zależności od potrzeb - stworzą ochronę przed nadmiernym nagrzewaniem się ścian przy dużej operacji słonecznej. Stosując różne gatunki alg będziemy mogli w prosty sposób zmieniać wizerunek wybranych przestrzeni miejskich. Jak wynika z przestawionych przykładów, tego typu aranżacje stają się elementami kształtującymi współczesne miasta, świadcząc o rozwoju nowych idei projektowych łączących w sobie zarówno ekologię jak i współczesną technologię, tworząc żywe instalacje. Te "żywe rzeźby" stają się dla przestrzeni miejskiej elementem symbiozy struktury nieożywionej z materią żywą, delikatną, ale również wrażliwą na brak dbałości w jej użytkowaniu. Pozwalają spojrzeć na miasto jako całość, jako ekosystem, w którym poszczególne elementy powinny ze sobą wspólistnieć i wzajemnie na siebie oddziaływać, by tworzyć zdrową i harmonijną przestrzeń życia dla człowieka, ale również dla zwierząt i roślin. Tego typu instalacje mają także znaczenie symboliczne, a nawet można powiedzieć filozoficzne.

Zastosowanie alg pomoże również w rozwoju miejskich farm, gdzie będzie można hodować żywność w sposób bardziej wydajny, zużywając mniej tak cennej powierzchni (uprawy w fotobioreaktorach zajmują mniej przestrzeni [13].) i efektywniej wykorzystując wodę.

W przyszłości algi mogą się stać elementem kreowania dużych obszarów parków wodnych, gdzie nie tylko będziemy mogli spędzać swój wolny czas, ale również uczyć się w jaki sposób racjonalnie wykorzystywać środowisko naturalne w naszym codziennym życiu.

\section{Literatura}

[1] https://www.forumforthefuture.org/greenfutures/articles/building-powered-algae \{dostęp 14.05.2016 r.\}.

[2] International Building Exhibition Hamburg, Smart Material House BIQ, Hamburg, 2013. 
[3] Urbańska M., Kłosowski G.: Algi jako materiał biosorpcyjny - usuwanie i odzysk metali ciężkich ze ścieków przemysłowych, Ochrona Środowiska i Zasobów Naturalnych $\mathrm{nr}$ 51, 2012, s. 68-77.

[4] Talbierz Sz., Kujawska N., Latała A.: Opatentowany fotobioreaktor do produkcji nowych leków i nutraceutyków wytwarzanych na bazie mikroalg, Przegląd Lekarski nr 69, 2012, s. 1031-1034.

[5] Javanmardian M., Paisson B.: Design and operation of an algal photobioreactor system, Advances in Space Research Vol. 12, no.5, 1992, pp. 231-235.

[6] The Parliamentary Office of Science and Technology Biofuels from Algae, London No. 3842011.

[7] Kyoung-Hee K.: A Feasibility Study of an Algae Façade System, International Conference on Sustainable Building Asia, 2013, pp. 333-341.

[8] Kolek Z.: Oddziaływanie promieniowania optycznego na człowieka: Korzystny wpływ i zagrożenia, Prace Instytutu Elektrotechniki, zeszyt 228, 2006, s. 269-281.

[9] http://inhabitat.com/algaegarden/ \{dostęp 14.05.2016 r.\}.

[10] http://biomassmagazine.com/articles/9341/real-green-heat \{dostęp 14.05.2016 r. $\}$.

[11] http://syndebio.com/urban-algae-canopy-ecologicstudio/ \{dostęp 14.05.2016 r. \}.

[12] http://syndebio.com/algaezebo/ \{dostęp 14.05.2016 r. \}.

[13] http://www.arup.com/projects/solarleaf \{dostęp 14.05.2016 r. \}.

[14] http://www.designboom.com/architecture/bureau-a-spirulina-fountain-garden-follyparc-des-evaux-confignon-geneva-01-16-2015/ \{dostęp 14.05.2016 r.\}.

[15] http://www.wayward.co.uk/work/garden/algaegarden \{dostęp 14.05.2016 r.\}.

[16] http://www.hok.com/thought-leadership/algae-powers-process-zero-conceptbuilding/\{dostęp 14.05.2016 r.\}.

\title{
NEW CONCEPT OF LANDSCAPE ARCHITECTURE USING MICROALGAE IN CREATING CITIES OF TOMORROW
}

\begin{abstract}
S u m m a r y
In the new ecological age, buildings, parks cites, communication passage do not only create spaces - they should promote the new concept of environmentally conscious in the cities. The concepts of microalgae can be the way how to do it. The simple use of these concept is to use microalgae as a part of green facades of building, green elements of communication passage, or in the city parks as a installation. It's a decorative function. But in the future microalgae can be used more like a producer oxygen, reducer $\mathrm{CO} 2$, water cleaner, producer bio fuel and even food - where buildings, parks cites and communication passage evolve from being passive form into adaptive and responsive objects - living, breathing -supporting the cities of next generation.
\end{abstract}

Keywords: microalgae, photobioreactors, green wall, landscape architecture

DOI: $10.7862 / \mathrm{rb} .2016 .254$

Przestano do redakcji: 30.06 .2016 r.

Przyjęto do druku: 20.12.2016 r. 
